\title{
HUBUNGAN USIA DAN STATUS PEKERJAAN IBU DENGAN KEJADIAN KURANG ENERGI KRONIS PADA IBU HAMIL
}

\section{RELATIONSHIP AGE AND OCCUPATIONAL STATUS WITH CHRONIC ENERGY DEFICIENCY IN PREGNANT WOMAN}

\author{
Aeda Ernawati \\ Badan Perencanaan Pembangunan Daerah Kabupaten Pati \\ Email : aeda.ernawati@yahoo.com \\ Naskah Masuk: 8 Maret 2018 \\ Naskah Revisi:11 April 2018 \\ Naskah Diterima:16 April 2018

\begin{abstract}
The number of pregnant women with chronic energy deficiency in Pati Regency increases in the last three years.The purpose of this study is to analyze the relationship the age factor and the occupation of pregnant women towardchronic energy deficiency in pregnant women in Puskesmas Gabus I. This studi uses a quantitative approach with cross sectional design.The study is conducted at Puskesmas Gabus I.The populationare 194 pregnant women and 132 of them are used as the study sample obtained by simple random sampling. Statistical test uses chi square and risk estimation uses rasio prevalence. The results show that there is a correlationbetween maternal age and occupationn chronic energy deficiency in pregnant women. Mothers who are pregnant at too young $(<20$ years) or too old (>35 years) have risk experiencing chronic energy deficiency. In addition, the pregnant women without job. Therefore, it is important to promote pregnancy at a healthy reproductive age as well as to improve household's incomes.
\end{abstract}

Keywords:chronic energy deficiency, maternal age, occupational status, pregnant women

\begin{abstract}
ABSTRAK
Prevalensi ibu hamil yang mengalami Kekurangan Energi Kronis (KEK) di Kabupaten Pati mengalami peningkatan. Data prevalensi ibu hamil KEK dari tahun 2014 sampai 2016 berturutturut yaitu 6,43\%, 7,47\%, dan 8,03\%.Tujuan penelitian untuk menganalisis faktor usia ibu hamil dan status pekerjaan terhadap kejadian KEK pada ibu hamil di Puskesmas Gabus I. Penelitian menggunakan pendekatan kuantitatif dengan desain studi cross sectional. Lokasi penelitian di Puskesmas Gabus I Jumlah populasi sebanyak 194 ibu hamil dan diambil sampel sebanyak 132 orang dengan teknik simple random sampling. Uji statistic menggunakan chi square dan estimasi risiko menggunaka rasio prevalence. Hasil penelitian menunjukkan ada hubungan usia ibu hamil dan status pekerjaan dengan kejadian KEK pada ibu hamil. Ibu yang hamil pada usia terlalu muda ( $<20$ tahun) atau terlalu tua (>35 tahun) berisiko mengalami KEK. Selain itu ibu hamil yang hanya beraktivitas sebagai ibu rumah tangga (tidak bekerja)berisiko mengalami KEK. Perlu upaya promosi kesehatan tentang pentingnya kehamilan di usia reproduksi sehat dan upaya peningkatanpenghasilan pada ibu rumah tangga.
\end{abstract}

Kata kunci : ibu hamil, kurang energi kronis, status pekerjaan, usia ibu 


\section{PENDAHULUAN}

Kualitas sumber daya manusia (SDM) menentukan keberhasilan suatu bangsa. Salah satu faktor yang mempengaruhi kualitas SDM adalah faktor kecukupan gizi. Gizi yang cukupdiperlukan untuk proses perkembangan otak dan pertumbuhan fisik. Oleh karena itu pemenuhan kecukupan gizi seseorang perlu dirancang sejak dini dimula saat masa kehamilan. Kebutuhan gizi yang tidak terpenuhi sejak awal kehidupan dapat menyebabkan kualitas kehidupan selanjutnya (Hamzah, 2017).

Kementerian Kesehatan RI (2014a) menyebutkan bahwa pemenuhan gizi anak sangat penting pada 1000 Hari Pertama Kehidupan (HPK) karena pada periode ini terjadi pertumbuhan otak yang sangat pesat dan mendukung seluruh proses pertumbuhan anak dengan sempurna. Jika pada rentang usia tersebut anak tidak mendapatkan asupan gizi yang optimal, maka dapat menyebabkan pertumbuhan otak terhambat, anak tidak cerdas, pertumbuhan jasmani dan perkembangan kemampuan anak terhambat, anak lemah dan mudah sakit serta kemampuan belajarnya rendah. Kondisi ini tidak akan dapat diperbaiki pada periode kehidupan selanjutnya. Periode 1000 Hari Pertama Kehidupan (HPK) dimulai pada periode dalam kandungan (280 hari).

Gizi yang berkualitas dalam jumlah yang cukup sangat dibutuhkan untuk kesehatan ibu hamil dan janin dalam kandungan. Salah satu kebutuhan zat gizi yang meningkat selama kehamilan adalah tambahan energi sekitar 300 kkal per hari. Penambahan konsumsi energi pada trimester II diperlukan untuk pertumbuhan jaringan ibu, seperti penambahan volume darah, pertumbuhan uterus dan payudara, serta penumpukan lemak. Sepanjang trimester
III, energi tambahan dipergunakan untuk pertumbuhan janin dan plasenta (Arisman, 2004). Jika kebutuhan energi ini tidak terpenuhi, maka akan menimbulkan masalah kesehatan yaitu Kurang Energi Kronis (KEK).

Kondisi ibu hamil KEK berisiko menurunkan kekuatan otot yang membantu proses persalinan sehingga dapat mengakibatkan terjadinya partus lama dan perdarahan pascapersalinan, bahkan kematian ibu. Risiko pada bayi dapat mengakibatkan terjadi keguguran, prematur, lahir cacat, Bayi Berat Lahir Rendah (BBLR) bahkan kematian bayi. Ibu hamil KEK dapat mengganggu tumbuh kembang janin seperti pertumbuhan fisik, otak dan metabolisme yang menyebabkan penyakit tidak menular saat dewasa (Kemenkes RI, 2013).

Data hasil riset kesehatan dasar (Riskesdas) 2013 menunjukkan prevalensi risiko KEK pada Wanita Usia Subur (WUS) usia 15-49 tahun sebesar $20,8 \%$. Prevalensi risiko KEK pada kelompok WUS usia20-24 tahun sebesar $30,6 \%$. Adapun prevalensi risiko KEK tertinggi ditemukan pada WUS remaja (15-19 tahun) yaitu sebesar 46,6\% . Sedangkan prevalensi risiko KEK pada ibu hamil (15-49 tahun) sebesar 24,2\%. Prevalensi tertinggi risiko KEK pada ibu hamil ditemukan pada ibu hamil usia remaja (15-19 tahun) yaitu sebesar 38,5\%.Prevalensi risiko KEK pada kelompok ibu hamil usia 20-24 tahun sebesar 30,1\%.

Data ibu hamil KEK di Kabupaten Pati dalam tiga tahun terakhir selalu mengalami peningkatan. Prevalensi ibu hamil KEK di Kabupaten Pati dari tahun 2014-2016 berturut-turut yaitu 6,43\%, $7,47 \%$, dan $8,03 \%$. Ibu hamil KEK tersebar di 29 Puskesmas di Kabupaten Pati. Prevalensi ibu hamil KEK di Puskesmas Gabus I sejak tahun 2014 sampai tahun 2016 dan selalu masuk 
peringkat 5 besar di Kabupaten Pati.Prevalensi ibu hamil KEK di Puskesmas Gabus I Pati dari tahun 20142016 berturut-turut yaitu 12,30\%, 19,68\%, dan 26,56\% (Dinas Kesehatan Kab. Pati, 2016). Oleh karena itu, masalah gizi kurang KEK pada ibu hamil menjadi salah satu fokus perhatian untuk ditanggulangi.

Menurut Mahirawati (2014), faktor usia ibu hamildan status pekerjaan berhubungan dengan kejadian KEK pada ibu hamil. Tujuan penelitian untuk menganalisis hubunganusiaibu dan status pekerjaan dengan kejadian KEK pada ibu hamil di Puskesmas Gabus I. Rekomendasi dari hasil penelitian ini diharapkan mampu membantu pemerintah dalam mengatasi masalah gizi kurang pada ibu hamil di Kabupaten Pati.

\section{TINJAUAN PUSTAKA}

\section{Kehamilan}

Kehamilan adalah proses alamiah yang dialami wanita. Kehamilan merupakan suatu proses yang berkesinambungan dan terdiri dari ovulasi pelepasan sel telur, migrasi spermatozoa dan ovum, konsepsi dan pertumbuhan zigot, nidasi (implantasi) pada uterus, pembentukan plasenta, dan tumbuh kembang hasil konsepsi sampai aterm atau cukup bulan untuk lahir. Masa kehamilan berlangsung dalam waktu 280 hari (40 minggu) dan terbagi dalam 3 triwulan. Triwulan pertama dimulai dari hasil konsepsi sampai kehamilan usia 3 bulan. Triwulan kedua dimulai dari bulan ke-4 sampai 6 bulan, sedangkan triwulan ketiga dimulai dari bulan ke-7 sampai 9 bulan (Manuaba, dkk., 2009).

Wanita hamil merupakan salah satu kelompok yang rawan gizi. Kelompok rentan gizi adalah suatu kelompok dalam masyarakat yang paling mudah menderita gangguan kesehatanatau rentan terjadi masalah kesehatan seperti kekurangan gizi (Notoatmodjo, 2011).Peraturan Menteri Kesehatan RI No. 97 tahun 2014 menyebutkan salah satu jenis pemeriksaan antenatal pada ibu hamil adalah pemeriksaanLingkar Lengan Atas (LiLA). Adapun tujuan pemeriksaan LiLA untuk mendeteksi kemungkinan terjadinya masalah gizi pada ibu hamil. Oleh sebab itu penting untuk menyediakan kebutuhan gizi yang cukup selama kehamilan agar ibu hamil dapat memperoleh dan mempertahankan status gizi yang optimal. Ibu hamil dengan status gizi yang baik dapat menjalani kehamilan dengan aman. Ibu hamil dapat melahirkan bayi dengan potensi fisik dan mental yang baik, serta memperoleh energi yang cukup untuk menyusui bayinya (Arisman, 2007).

Masa hamil merupakan bagian yang harus diperhatikan karena merupakan bagian dari 1000 hari pertama kehidupan. Beberapa hal yang perlu diperhatikan ibu hamil agar kebutuhan gizi bayi dapat terpenuhi dengan sempurna adalah: a) makan lebih banyak (dua porsi) dan beraneka ragam lauk pauk, sayur dan buah; b) minum tablet tambah darah 1 butir sehari dari total 90 tablet besi selama tiga bulan; c) tidak merokok; d)tidak munum minuman bersoda dan beralkohol; e)tidak makan mie instan sebagai makanan pokok; f) menghindari makanan berpengawet; g) tidak minum obat tanpa resep dokter; h) mengikuti kelas ibu hamil; i) melakukan perawatan payudara untuk persiapan menyusui; j) melakukan pemeriksaan kehamilan dan merencanakan persalinan dengan petugas kesehatan (Kemenkes RI, 2014a).

\section{Kebutuhan Gizi Ibu Hamil}

Konsumsi makanan ibu hamil harus memenuhi kebutuhan untuk dirinya dan untuk pertumbuhan serta perkembangan janin/bayinya. Oleh 
karena itu, ibu hamil membutuhkan zat gizi yang lebih banyak dibandingkan dengan keadaan tidak hamil. Jenis konsumsi pangannya tetap beranekaragam dan seimbang dalam jumlah dan proporsinya. Janin tumbuh dengan mengambil zat-zat gizi dari makanan yang dikonsumsi oleh ibunya dan dari simpanan zat gizi yang berada di dalam tubuh ibunya melalui plasenta. Selama hamil, ibu harus menambah jumlah dan jenis makanan yang dimakan untuk mencukupi kebutuhan pertumbuhan bayi dan kebutuhan ibu serta untuk memproduksi ASI. Bila makanan ibu sehari-hari tidak mengandung zat gizi yang cukup sesuai kebutuhan, maka janin atau bayi akan mengambil persediaan yang ada di dalam tubuh ibunya, seperti sel lemak ibu sebagai sumber kalori dan zat besi dari simpanan di dalam tubuh ibu sebagai sumber zat besi bagi janin atau bayi. Oleh karena itu, ibu hamil harus mempunyai status gizi yang baik sebelum hamil dan mengonsumsi makanan yang beranekaragam (Kemenkes RI, 2014b).

Peraturan Menteri Kesehatan Republik Indonesia, Nomor 75 Tahun 2013 tentang Angka Kecukupan Gizi yang Dianjurkan bagi Bangsa Indonesia memberi panduan tentang angka kebutuhan gizi berdasarkan jenis kelamin dan umur (berdasarkan berat badan \& tinggi badan). Salah satu kebutuhan zat gizi yang meningkat selama kehamilan adalah kebutuhan energi. Pertambahan energi terutama terjadi pada trimester II dan III. Penambahan konsumsi energi pada trimester II diperlukan untuk pertumbuhan jaringan ibu seperti penambahan volume darah, pertumbuhan uterus dan payudara, serta penumpukan lemak. Adapun penambahan konsumsi energi sepanjang trimester III digunakan untuk pertumbuhan janin dan plasenta (Arisman, 2007).
Angka Kecukupan Gizi ibu hamil merupakan penjumlahan dari kebutuhan gizi ibu hamil (sesuai dengan umur, berat badan dan tinggi badan) dan penambahan kebutuhan zat gizi sesuai usia kehamilan. Penambahan energi pada trimester 1 sebanyak $180 \mathrm{kkal} / \mathrm{hari}$, sedangkan pada trimester 2 dan 3 sama banyak yaitu masing-masing300kkal/hari. Adapun Penambahan kebutuhan protein pada trimester 1 , trimester 2 , dan trimester 3 besarnya sama yaitu masing-masing 20 gram/hari.

Jika kebutuhan gizi ibu hamil tidak terpenuhi, maka dapat terjadi masalah gizi pada ibu hamil. Masalah gizi yang dialami ibu hamil dapat mengganggu kesehatan ibu dan janin, sehingga pemenuhan gizi pada ibu hamil menjadi penting. Saat ini masih banyak ibu hamildi Indonesia yang mengalami masalah gizi khususnya gizi kurang seperti Kurang Energi Kronik (KEK) dan anemia (Kementerian Kesehatan, 2014b).

\section{Kekurangan Energi Kronis (KEK)}

Malnutrisi adalah keadaan patologis akibat kekurangan atau kelebihan secara relatif atau absolut satu atau lebih zat gizi. KEK merupakan salah satu keadaan malnutrisi (Supriasa dkk, 2016). KEK merupakan salah satu masalah kurang gizi yang sering terjadipada wanita hamil, yang disebabkan oleh kekurangan energi dalam jangka waktu yang cukup lama. KEK pada wanita di negara berkembang merupakan hasil komulatif dari keadaan kurang gizi sejak masa janin, bayi, kanak-kanak dan berlanjut hingga dewasa (Hasanah dkk, 2013).

Jenis antropometri yang digunakan untuk mengukur risiko KEK pada wanita usia subur (WUS)/ibu hamil adalah lingkar lengan atas (LiLA). WUS di Indonesia berisiko menderita KEK jika ukuran LiLA kurang dari $23,5 \mathrm{~cm}$ atau di bagian merah pita LiLA. Apabila hasil 
pengukuran LiLA lebih dari $23,5 \mathrm{~cm}$ maka WUS tersebut tidak berisiko menderita KEK atau status gizinya dalam kategori baik (Supariasa dkk, 2016).

\section{Akibat KEK}

KEK pada ibu hamil berdampak pada kesehatan ibu dan janin yang sedang dikandungnya. Wijanti, dkk (2016) menyatakan ibu hamil yang menderita KEK mempunyai risiko kematian mendadak pada masa perinatal, kematian saat persalinan, pendarahan, pasca persalinan yang sulit karena lemah dan mudah mengalami gangguan kesehatan. Penelitian Aminin, dkk (2014) menunjukkan ada hubungan KEK pada ibu hamil dengan anemia. Selain itu KEK pada ibu hamil juga dapat meningkatkan risiko terjadinya Berat Bayi lahir Rendah (BBLR). Bayi Lahir Rendah (BBLR) adalah bayi dengan berat lahir kurang dari 2500 gram. Kejadian BBLR di Indonesia berdasarkan hasil Riskesdas (2013) menunjukkan persentase balita (059 bulan) yang mengalami BBLR sebesar 10,2\%. Bayi dengan BBLR mempunyai risiko kematian lebih tinggi dari bayi yang lahir normal. BBLR diperkirakan menyebabkan kematian 20 kali dibandingkan dengan bayi yang beratnya lebih dari 2500 gram. BBLR merupakan masalah kesehatan karena BBLR menjadi salah satu penyebab utama kematian neonatal. Depkes RI (2008) menyebutkan sebanyak 15-20\% kematian bayi di Indonesia disebabkan karena BBLR. Selain itu, BBLR dapat menurunkan kualitas generasi yang akan datang karena memperlambat pertumbuhan dan perkembangan mental anak serta menyebabkan penurunan kecerdasan (IQ) 10-13 poin (Amalia, 2011). Hasil penelitian Nova, (2011) menunjukkan anak SD dengan riwayat BBLR mempunyai skor IQ yang lebih rendah dibandingkan anak SD dengan riwayat lahirdengan berat badan cukup.
Kebutuhan energi dan zat gizi lainnya meningkat selama kehamilan. Peningkatan energi dan zat gizi lainnya yang tidak terpenuhi dapat menyebabkan pertumbuhan dan perkembangan janin tidak sempurna.Akibat lain dari KEK adalah kerusakan struktur susunan syaraf pusat terutama pada tahap pertama pertumbuhan otak (hiperplasia) yang terjadi selama dalam kandungan. Masa rawan pertumbuhan sel-sel saraf terjadi pada trisemester 3 kehamilan sampai sekitar 2 tahun setelah lahir. Kekurangan gizi pada masa dini perkembangan otak akan menghentikan sintesis protein dan DNA. Akibatnya pertumbuhan otak terganggu sehingga sel-sel otak yang berukuran normal lebih sedikit. Dampaknya akan terlihat pada struktur dan fungsi otak di masa mendatang yang berpengaruh pada intelektual anak (Soetjiningsih, 2009).

\section{Faktor-faktor yang Mempengaruhi KEK}

Beberapa penelitian menunjukkan usia ibu hamil dan status pekerjaan ibu berhubungan dengan kejadian KEK pada ibu hamil. Semakin muda dan semakin tua umur seseorang ibu yang sedang hamil akan berpengaruh terhadap kebutuhan gizi yang diperlukan. Umur muda perlu tambahan gizi yang banyak karena selain digunakan pertumbuhan dan perkembangan dirinya sendiri, juga harus berbagi dengan janin yang sedang dikandung. Sedangkan untuk umur tua perlu energi yang besar juga karena fungsi organ yang melemah dan diharuskan untuk bekerja maksimal, maka memerlukan tambahan energi yang cukup guna mendukung kehamilan yang sedang berlangsung. Sehingga usia yang paling baik adalah lebih dari 20 tahun dan kurang dari 35 tahun, denganharapan gizi ibu hamil akan lebih baik.

Aktifitas dan gerakan seseorang berbeda-beda. Seseorang yang bergerak 
otomatis memerlukan energi yang lebih besar dari pada mereka yang hanya duduk diam saja. Setiap aktifitas memerlukan energi, maka apabila semakin banyak aktifitas yang dilakukan, energi yang dibutuhkan juga semakin banyak. Kebutuhan gizi ibu hamil yang bekerja tentunya lebih tinggi dari ibu hamil yang tidak bekerja. Seorang ibu hamil yang bekerja membutuhkan zat gizi untuk aktivitas kerja, kesehatan ibu hamil dan janin (Depkes RI, 1991).

\section{METODE PENELITIAN}

Penelitian ini menggunakan pendekatan kuantitatif dengan desain studi cross sectional. Variabel terikatnya kejadian ibu hamil KEK, sedangkan variabel bebasnya adalahusia ibu hamil dan status pekerjaan ibu.Populasi dalam penelitian ini adalah seluruh ibu hamil yang tercatat di wilayah Puskesmas Gabus I Kabupaten Pati pada bulan April 2017 yaitu sebanyak 194 ibu hamil. Sampel dihitung berdasarkan tabel krejcie dengan tingkat kesalahan 5\% sehingga didapatkan jumlah sampel minimal sebanyak 132 orang. Instrumen penelitian yang digunakan dalam penelitian ini adalah lembar cek list dan KMS ibu hamil.Analisis data menggunakan uji statistik chi square(Sugiyuno, 2013).

\section{HASIL DAN PEMBAHASAN}

\section{Status gizi ibu hamil}

Status gizi ibu hamil digolongkan menjadi ibu hamil dengan status gizi baik dan ibu hamil yang mengalami kekurangan energi kronis (KEK). Ibu hamil yang memiliki ukuran LILA $\geq 23,5$ $\mathrm{cm}$ menunjukkan bahwa ibu hamil mempunyai status gizi baik sedangkan ibu hamil yang mempunyai ukuran LILA kurang dari $23,5 \mathrm{~cm}$ dikategorikan sebagai ibu hamil yang mengalami Kurang Energi Kronis (KEK). Berdasarkan Tabel 1, dapat diketahui bahwa sebagian besar ibu hamil di Puskesmas Gabus I mempunyai status gizi yang baik yaitu sebanyak 107 orang $(81,1 \%)$. Adapun ibu hamil yang mengalami KEK sebanyak 25 orang $(18,9 \%)$. Angka ini lebih rendah dari angka prevalensi risiko KEK wanita hamil usia 15-49 tahun di Indonesia tahun 2013 yaitu sebanyak 24,2\%.

\section{Umur ibu}

Umur ibu hamil digolongkan menjadi dua yaitu berisiko dan tidak berisiko. Umur berisiko maksudnya umur ibu hamil mempunyai risiko tinggi jika mengalami kehamilan. yaitu umur terlalu muda ( $<20$ tahun) dan terlalu tua ( $>35$ tahun). Umur tidak berisiko maksudnya umur ibu yang dianjurkan untuk mengalami kehamilan yaitu usia 20-35 tahun. Hasil penelitian menunjukkan bahwa sebagian besar ibu hamil berumur 20-35 tahun yaitu sebanyak 103 orang (78\%) dan ibu hamil yang berumur $<20$ tahun atau $>35$ tahun sebanyak 29 orang (22\%). Hasil penelitian ini lebih tinggi dari hasil penelitian Musni, dkk (2017) di UPT Puskesmas Ajangale Kabupaten Bone Provinsi Sulawesi Selatan yang menunjukkan ibu hamil yang termasuk usia berisiko mengalami KEK yaitu sebanyak $20,3 \%$.

Kehamilan di usia muda terjadi karena pernikahan dilakukan pada usia muda. Djamilah dan Kartikawati (2014) menyatakan bahwa dampak signifikan dari pernikahan usia muda adalah ibu muda tidak tahu atau tidak memahami masalah kehamilan. Ibu tidak memahami kebutuhan gizi bagi ibu hamil. Kondisi ini dapat menyebabkan anak yang dilahirkan menjadi kurang gizi yaitu bayi lahir dengan berat badan yang rendah (BBLR).

Sementara saat ini kehamilan di usia 35 tahun atau lebih cenderung meningkat. Kondisi ini kemungkinan disebabkan semakin berkembangnya 
bidang pendidikan dan lapangan kerja bagi kaum wanita. Wanita yang berpendikan tinggi berupaya mencari kerja untuk mengaktualisasikan diri. Akhirnya banyak wanita yang terlambat untuk berkeluarga (Pontoh dkk, 2015).

\section{Status Pekerjaan}

Status pekerjaan ibu hamil digolongkan menjadi dua yaitu bekerja dan tidak bekerja. Hasil penelitian menunjukkan bahwa sebagian besar ibu hamil tidak bekerja (beraktivitas sebagai ibu rumah tangga) yaitu sebanyak 76orang $(57,6 \%)$ dan sebanyak 27 orang ibu hamil $(20,5 \%)$ bekerja. Adapun yang tidak menjawab pertanyaan sebanyak 29 orang $(22,0 \%)$.
Saat ini perempuan memiliki kesempatan yang sama dalam bidang pendidikan sehingga semakin banyak perempuan memiliki pendidikan yang baik. Lapangan pekerjaan juga banyak tersedia bagi perempuan. Perempuan yang dimasa lajangnya sudah bekerja nampaknya akan terus bekerja meskipun sudah menikah. Mereka sebagai ibu rumah tangga terus bekerja dengan berbagai motivasi dan alasan seperti kebutuhan aktualisasi diri dan perlunya membantu ekonomi rumah tangga. Peranan perempuan dalam pembangunan terus didorong dalam segala aspek kehidupan (Sudirman, 2016).

Tabel 1.

Distribusi Ibu Hamil Berdasarkan Variabel yang Diteliti

\begin{tabular}{llcc}
\hline \multicolumn{1}{c}{ Variabel Penelitian } & \multicolumn{1}{c}{ Kategori } & $\begin{array}{c}\text { Jumlah } \\
(\mathrm{n})\end{array}$ & $\begin{array}{c}\text { Persentase } \\
(\%)\end{array}$ \\
\hline Kurang EnergiKronis & KEK & 25 & 18,9 \\
& Tidak KEK & 107 & 81,1 \\
Umur ibu hamil & $<20$ atau $>35$ & 25 & 18,9 \\
\multirow{3}{*}{ Status Pekerjaan } & 20-35 tahun & 107 & 81,1 \\
& Tidak bekerja & 76 & 57,6 \\
& Bekerja & 27 & 20,5 \\
& Tidak menjawab & 29 & 22,0 \\
\hline
\end{tabular}

Sumber: Data Penelitian (2017)

\section{Hubungan umur ibu dengan kejadian} KEK pada ibu hamil

Umur ibu merupakan salah satu faktor penting dalam proses kehamilan sampai persalinan. Hasil penelitian menunjukkan sebagian besar ibu hamil termasuk dalam kelompok usia reproduksi sehat yaitu usia 20-35 tahun, baik pada kelompok ibu hamil yang mengalami KEK maupun kelompok ibu hamil yang tidak mengalami KEK.Hasil uji statistik diperoleh nilai $\mathrm{p}=0,03$ dan nilai rasio prevalens sebesar 4,089. Artinya ibu yang usianya terlalu muda ( $<20$ tahun) atau terlalu tua ( $>35$ tahun) berisiko mengalami KEK pada saat hamil sebesar 4,089 kali dibandingkan ibu hamil pada usia 20-35 tahun. Hal ini menunjukkan bahwa ada pengaruh usia ibu hamil terhadap kejadian KEK.

Proverawati \& Asfuah (2009) menyebutkan ibu yang mengalami kehamilan pada usia muda ( $<20$ tahun) atau usia tua ( $>35$ tahun) membutuhkan zat gizi yang lebih banyak dari pada ibu yang hamil pada saat usia reproduksi sehat (usia 20-35 tahun). Kehamilan yang terjadi pada usia muda menyebabkan terjadinya kompetisi pemenuhan zat gizi antara janin dan ibunya. Ibu yang hamil 
pada saat usia remaja atau kurang dari 20 tahun memerlukan zat gizi yang banyak untuk memenuhi kebutuhan gizi ibu dan janin yang sedang dikandungnya.Hal ini terjadi karena ibu masih dalam usia pertumbuhan (Mahirawati, 2014). Pertumbuhan dan perkembangan yang pesat terjadi pada usia remaja. Usia kurang dari 20 tahun termasuk usia remaja (Notoatmodjo, 2011).

Adapun ibu hamil yang berusia lebih dari 35 tahun memiliki organ tubuh yang fungsinya semakin melemah. Pengaruh proses penuaan juga mulai muncul. Kondisi ini ditandai adanya penyakit hipertensi dan diabetes mellitus yang dapat menghambat masuknya makanan bagi janin melalui plasenta. Oleh karena itu wanita yang hamil pada usia lebih dari 35 tahun memerlukan energi yang besar untuk mendukung kehamilannya (Kristiyanasari, 2010; Yana dkk, 2016).

Hasil penelitian ini selaras dengan hasil penelitian Handayani \& Budianingrum (2011) yang menyatakan bahwa ada hubungan antara umur ibu hamil dengan KEK pada ibu hamil di wilayah Puskesmas Wedi Klaten.

\section{Hubungan status pekerjaan ibu dengan KEK pada ibu hamil}

Ibu hamil yang mengalami KEK di Puskesmas Gabus 1 Kabupaten Pati sebagian besar terdapat pada kelompok ibu yang tidak bekerja atau beraktivitas sebagai ibu rumah tangga. Hasil uji statistik diperoleh nilai $\mathrm{p}=0,012$ dan nilai Rasio prevalens sebesar 9,286. Artinya ibu hamil yang tidak bekerja berisiko mengalami KEK sebesar 9,286 kali dibandingkan ibu hamil yang bekerja.

Hasil penelitian Permatasari, dkk (2008) menunjukkan bahwa perempuan yang bekerja memiliki kemampuan untuk mengenali masalah kesehatan keluarga. Pengetahuan perempuan bekerja tentang masalah kesehatan didapatkan dari buku, majalah, koran, radio dan televisi. Perempuan yang bekerja memiliki kemampuan mengambil keputusan untuk mengatasi masalah kesehatan yang dihadapi. Oleh karena itu wanita yang berperan sebagai pekerja sekaligus sebagai seorang istri dan ibu rumah tangga umumnya memiliki kesehatan yang lebih baik (Najoan \& Manampiring, 2011).

Tabel 2.

Hasil Uji Statistik Variabel yang Diteliti

\begin{tabular}{|c|c|c|c|c|c|c|}
\hline \multirow{3}{*}{ Variabel } & \multicolumn{4}{|c|}{ Ibu Hamil } & \multirow{3}{*}{ Nilai P } & \multirow{3}{*}{$\begin{array}{c}\text { Rasio } \\
\text { Prevalens }\end{array}$} \\
\hline & \multicolumn{2}{|c|}{ KEK } & \multicolumn{2}{|c|}{ Tidak KEK } & & \\
\hline & $\mathrm{n}$ & $\%$ & $\mathrm{n}$ & $\%$ & & \\
\hline \multicolumn{7}{|l|}{ Umur ibu hamil } \\
\hline$<20$ atau $>35$ & 10 & 40,0 & 15 & 60,0 & 0,003 & 4,089 \\
\hline 20-35 tahun & 15 & 14,0 & 92 & 86,0 & & \\
\hline \multicolumn{7}{|l|}{ Status Pekerjaan Ibu } \\
\hline Tidak bekerja & 20 & 26,3 & 56 & 73,7 & 0,012 & 9,286 \\
\hline Bekerja & 1 & 3,7 & 26 & 96,3 & & \\
\hline
\end{tabular}

Sumber: Data Penelitian (2017)

Seseorang yang bekerja dapat meningkatkan pengetahuan karena pengalaman dan pergaulan serta dan interaksi sosial yang luas (Notoatmodjo,
2007). Pernyataan ini sesuai dengan hasil penelitian Permatasari, dkk (2008) yang menyebutkan bahwa motivasi perempuan untuk bekerja adalah untuk 
memperluas pergaulan dan menambah wawasan. Perubahan pengetahuan akan membawa perubahan pada sikap, perilaku, pendapatan, dan pola makan. Perubahan tersebut akan mempengaruhi pemilihan jenis dan jumlah makanan yang dikonsumsi. Selain itu ibu yang bekerja dapat meningkatkan status sosial ekonomi keluarga. Ibu bekerja mempunyai penghasilan sendiri sehingga untuk memenuhi kebutuhan gizinya tidak bergantung pada suaminya. Kondisi ini sesuai dengan pendapat Arisman (2007) yang menyebutkan bahwa pekerjaan berpengaruh terhadap status ekonomi. Kebutuhan kesehatan seperti terpenuhinya sarana kesehatan dan kebutuhan gizi dapat terpenuhi jika keluarga memiliki kemampuan secara ekonomi.

Hasil penelitian ini sejalan dengan penelitian Musni, dkk (2017) di UPT Puskesmas Ajangale Kabupaten Bone Provinsi Sulawesi Selatan. Penelitian tersebut menyatakan ada hubungan pekerjaan dengan kejadian KEK pada ibu hamil. Hasil penelitian menunjukkan semua kejadian KEK pada ibu hamil terjadi pada ibu hamil yang tidak bekerja. Hasil penelitian Indriyani, dkk (2014) menunjukkan hasil yang sama yaitu proporsi ibu hamil yang mengalami KEK lebih banyak terjadi pada kelompok ibu hamil yang tidak bekerja.

\section{KESIMPULAN DAN SARAN}

\section{Kesimpulan}

Sebanyak 18,9\% ibu hamil di Puskesmas Gabus I mengalami KEK. Proporsi ibu hamil berusia kurang dari 20 tahun dan lebih dari 35 tahun yang mengalami KEK lebih tinggi dari pada proporsi ibu hamil yang berusia 20-35 tahun yang mengalami KEK. Proporsi ibu hamil yang bekerja (beraktivitas sebagai ibu rumah tangga) dan mengalami KEK lebih tinggi dari pada proporsi ibu hamil yang bekerja dan mengalami KEK. Ada hubungan usia ibu hamil dan status pekerjaan dengan kejadian KEK pada ibu hamil di Puskesmas Gabus I Kabupaten Pati. Ibu yang hamil pada usia terlalu muda $(<20$ tahun) atau terlalu tua ( $>35$ tahun) berisiko mengalami KEK. Ada hubungan status pekerjaan dengan kejadian KEK pada ibu hamil di Puskesmas Gabus I Kabupaten Pati. Ibu hamil yang hanya beraktivitas sebagai ibu rumah tangga (tidak bekerja) berisiko mengalami KEK.

\section{Saran}

Dinas Kesehatan perlu melakukan upaya promosi kesehatan tentang pentingnya kehamilan di usia reproduksi sehat dan pentingnya pengetahuan tentang faktor yang berhubungan dengan KEK. Selain itu perlu usaha peningkatan penghasilan ibu rumah tangga misalnya melalui pelatihan ketrampilan yang dapat dilakukan di lingkungan rumah tangga. Ketrampilan yang dimiliki ibu rumah tangga bisa dimanfaatkan untuk meningkatkan ekonomi keluarga sehingga kebutuhan kesehatan dan gizi keluarga terpenuhi.

\section{DAFTAR PUSTAKA}

Amalia, L. (2011). Faktor Risiko Kejadian Bayi Berat Lahir Rendah (BBLR) di RSU Dr. MM Dunda Limboto Kabupaten Gorontalo. Jurnal Saintek, 6(3)

Aminin, F., Wulandari, A., Lestari, R. P. (2014). Pengaruh Kekurangan Energi Kronis (KEK) dengan Kejadian Anemia pada Ibu Hamil. Jurnal Kesehatan, V(2), 167-172

Arisman. (2007). Gizi dalam Daur Kehidupan. Jakarta: EGC;

Departemen Kesehatan RI. (2008). Manajemen Bayi Berat Lahir Rendah (BBLR) untuk Bidan Desa: Buku Acuan: Jakarta: Depkes RI. 
Departemen Kesehatan RI. (1991). Upaya Kesehatan Kerja Sektor Informal di Indonesia. Jakarta: Depkes RI

Dinas Kesehatan Kabupaten Pati. (2016). Data Ibu Hamil KEK di Kabupaten Pati Tahun 2014-2016. Pati: Dinas Kesehatan Kab. Pati

Djamilah \& Kartikawati, R. (2014). Dampak Perkawinan Anak di Indonesia. JURNAL STUDI PEMUDA, 3(1), 1-16

Hamzah, D. Z. (2017). Analisis Faktor yang Mempengaruhi Kejadian Kekurangan Energi Kronis (KEK) pada Ibu hamil di Wilayah Kerja Puskesmas Langsa Kota langsa Provinsi Aceh Tahun 2006. Jurnal Jumantik, 2(2), 1-11.

Handayani, S., Budianingrum S. (2011). Analisis Faktor yang Mempengaruhi Kekurangan Energi Kronis pada Ibu Hamil di Wilayah Puskesmas Wedi Klaten. Jurnal Involusi Kebidanan, 1(1), 42-60

Hasanah, D. N., Febrianti., Minsarnawati. (2013). Kebiasaan Makan Menjadi Salah Satu Penyebab, Kekurangan Energi Kronis (KEK) pada Ibu Hamil di Poli Kebidanan RSI\&A Lestari Cirendeu Tangerang Selatan. Jurnal Kesehatan Reproduksi, 4(2), 91-104

Indriyani., Helmiyati, S., Astria, B. (2014). Tingkat Sosial Ekonomi tidak Berhubungan dengan Kurang Energi Kronik (KEK) pada Ibu Hamil. Jurnal Gizi dan Dietetik Indonesia, 2(3), 116-125

Kementerian Kesehatan RI. (2013).Riset Kesehatan Dasar Tahun 2013. Jakarta: Balitbang Kemenkes RI.
Kementerian Kesehatan RI. (2014a). Keluarga Sehat Idamanku Kota Sehat Kotaku. Jakarta: Puspromkes Kemenkes RI

Kementerian Kesehatan RI. (2014b). Pedoman Gizi Seimbang. Jakarta

Kristiyanasari,W. (2010). Gizi Ibu Hamil. Yogyakarta: Nuha Medika

Mahirawati, V. K. (2014). Faktor-faktor yang Berhubungan dengan Kekurangan Energi Kronis. Buletin Penelitian Sistem Kesehatan, 17(2), 193-202.

Manuaba, I. A. C., Manuaba, I. B. G. F., Manuaba, I. B. G. (2009). Mamahami Kesehatan Reproduksi Wanita. Jakarta: EGC.

Musni., Malka., Asriyani, R. (2017) Faktor-faktor yang berhubungan dengan Kekurangan Energi Kronik (KEK) pada Ibu Hamil di UPTD Puskesmas Ajangale. Jurnal Ilmiah Kesehatan Diagnosis,11(1), 57-62

Najoan, J., Manampiring, A. (2011). Hubungan Kurang Tingkat Sosial Ekonomi dengan Kurang Energi Kronik pada Ibu Hamil di Kelurahan Krombos Barat Kecamatan Singkil Kota Manado. Manado: Universitas Sam Ratulang

Notoatmodjo, S. (2011). Kesehatan. Masyarakat Ilmu \& Seni. Jakarta: Rineka Cipta.

Nova, S. A. (2011). Perbedaan Tingkat Kecerdasan Intelektual (Intelligence Quotient-IQ) pada Anak Usia Sekolah Dasar dengan Riwayat BBLR (Bayi Berat Lahir Rendah) dan BBLC (Bayi Berat Lahir Cukup). Surakarta: Universitas Sebelas Maret 
Peraturan Menteri Kesehatan Republik Indonesia, Nomor 75 Tahun 2013 tentang Angka Kecukupan Gizi yang Dianjurkan bagi Bangsa Indonesia

Peraturan Menteri Kesehatan RI No. 97 tahun 2014 tentang Pelayanan Kesehatan Masa Sebelum hamil, Masa Hamil, Persalinan, dan Masa Sesudah Melahirkan, Penyelenggaraan Pelayanan Kontrasepsi, serta Pelayanan Kesehatan Seksual

Permatasari, H., Hamid, A. Y. S., Setyowati (2008), Pengalaman Perempuan Bekerja dalam Melaksanakan Tugas Kesehatan Keluarga di Wilayah Jakarta, Bogor, Tangerang, Bekasi. Jurnal Keperawatan Indonesia, 12(1), 2128.

Pontoh, V. Y. Y., Tendean, H. M. M., Suparman, E. (2015). Profil Persalinan pada Usia $\geq 35$ Tahun di RSUP Prof. Dr. R. D. Kandou Manado. Jurnal e-Clinic (eCI), 3(3)

Proverawati, A., Asfuah, S. (2009). Buku Ajar Gizi untuk Kebidanan, Yogyakarta: Numed Medika

Soetjiningsih. (2009). Tumbuh Kembang Anak. Jakarta: EGC.

Sudirman, D. (2016). Kontribusi dan Motivasi Pekerja Wanita dalam
Meningkatkan Ekonomi Keluarga. AL-ULUM ILMU SOSIAL DAN HUMANIORA, 1(2), 175-187.

Sugiyono. (2013). Statistika untuk Penelitian. Bandung: Alfabeta

Supariasa, I. D. N., Bakri, B., Fajar I. 2016. Penilaian Status Gizi. Jakarta: EGC.

Wijanti, R. E. Rahmanintyas, I., Suwoyo. (2016). Analisis Faktor Determinan Kejadian KEK pada Ibu Hamil di RSIA Citra Keluarga Kediri Tahun 2015. Jurnal Ilmu Kesehatan, 5(1), 73-86.

Yana., Musafaah., Yulidasari, F., (2016). Hubungan antara usia Ibu pasa Saat Hamil dan Status Anemia dengan Kejadian Berat Badan Lahir Rendah (BBLR).Studi observasional di Wilayah Kerja Puskesmas Martapura. Jurnal Publikasi Kesehatan masyarakat Indonesia, 3(1), 20-25.

\section{BIODATA PENULIS}

Aeda Ernawati, lahir di Purworejo pada tanggal 22 November 1976.Alumni S1 Kesehatan Masyatakat Universitas Diponegoro dan S2 Magister Gizi Masyarakat Universitas Diponegoro. Saat ini bekerja sebagai peneliti di Badan Perencanaan Pembangunan Daerah Kabupaten Pati. 